\title{
Olympus Corporation Financial Statement Fraud Case Study: The Role That National Culture Plays On Detecting And Deterring Fraud
}

Anita R. Morgan, Ohio Northern University, USA

Cori Burnside, Indiana University East, USA

\begin{abstract}
Recent cases provide insight into the role that an unethical corporate culture plays in financial statement fraud. The case of financial statement fraud in Olympus Corporation, a Japanese firm, provides the opportunity to examine how national culture plays a role in corporate governance and fraud detection. This case study focuses on the impact of Japanese culture on the corporate culture of The Olympus Corporation, and how that corporate culture resulted in financial statement fraud.
\end{abstract}

Keywords: Olympus Corporation; Financial Statement Fraud; Corporate Culture; Japanese Culture; Case Study

\section{BACKGROUND}

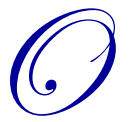

n April 1, 2011, Michael Woodford became the first non-Japanese president and COO of Olympus Corporation. He was fired six months later on October 14, 2011. In a press conference, Tsuyoshi Kikukawa, Chairman of the Board of Directors of Olympus stated, "We hoped that he could do things that would be difficult for a Japanese executive to do. But he was unable to understand that we need to reflect a management style we have built up in our 92 years as a company, as well as Japanese culture" (Dye, 2013).

Woodford's tenure as President was rocky. In July of 2011, after being in office only about three months, Woodford received an e-mail directing his attention to an article in a Japanese magazine (Facta) that accused Olympus of financial statement fraud. His questions to Kikukawa about the allegations against the company were not fully answered. In early August, Woodford learned that others in the company were instructed by Kikukawa not to tell him about the article in Facta. Kikukawa and other executives of the company began treating him coldly. In a series of letters to the Board of Directors, Woodford asked for details regarding the accounting transactions in question; he received no clear response to his questions, and was subsequently dismissed by the Board.

Realizing that the likelihood of financial statement fraud was high, Woodford blew the whistle on the company, exposing the suspect transactions. This case study focuses on the impact of Japanese culture on the corporate culture of The Olympus Corporation, and how that corporate culture resulted in fraud.

\section{FINANCIAL STATEMENT FRAUD}

According to the 2012 Report to the Nations (ACFE, 2012, p. 10) published by the Association of Certified Fraud Examiners, financial statement fraud is a scheme "in which an employee intentionally causes a misstatement or omission of material information in the organization's financial reports (e.g., recording fictitious revenues, understating reported expenses or artificially inflating reported assets)." While financial statement fraud was involved in less than $8 \%$ of the cases studied, it caused the greatest loss, with a median loss of $\$ 1$ million. Financial statement fraud can have a devastating effect on a corporation and its stakeholders; many cases end in bankruptcy of the firm. According to the report (p. 38): 
A poor tone at the top contributed to $9 \%$ of all the fraud cases reported to us, but was cited as the primary factor in $18 \%$ of cases that resulted in a loss of $\$ 1$ million or more. This reinforces the importance of a proper ethical tone from management in protecting an organization against the largest frauds - those cases that have the greatest potential to cripple the organization's finances and reputation.

\section{CORPORATE CULTURE AND FINANCIAL STATEMENT FRAUD}

Recent cases provide insight into the role that an unethical corporate culture plays in financial statement fraud. A corporate culture that emphasizes profits and stock prices creates an environment in which managers feel pressured to produce favorable financial statements (Summers \& Sweeney, 1998; Skousen \& Wright, 2006). This type of culture often provides incentives based on financial performance of the corporation. ${ }^{1}$ This is problematic because when managers have a significant personal financial stake in the corporation, they are more likely to misrepresent the financial position of the company (Beasley, 1996; Beasley, Carcello, \& Hermanson, 1999; Dunn, 2004; Skousen \& Wright, 2006). According to an article published in the New York Times, when Enron's stock hit $\$ 50$ per share, the company placed $\$ 100$ bills on employees' desks (Banerjee, 2002). Russ McGuire (2003), who worked for WorldCom for a brief period, states,

During my brief stay at WorldCom, the company's priorities were clearly communicated. Each department within the company had firm financial goals to meet. Whenever possible, individuals had specific financial goals. If you missed your goals for 1 month, you were put on warning. If you missed them for 3 months, you were gone. It was as simple as that. These requirements were always discussed within the context of creating shareholder value.

A corporate culture of secrets, centralized control, and a lack of transparency can provide the opportunity for fraud to be concealed. An organizational structure that gives the CEO and/or CFO too much control gives them the opportunity to conceal fraud (Loebbecke, 1989; Beasley, 1996, 1999; Abbott, Parker, \& Park, 2000; Dunn, 2004; Skousen \& Wright, 2006). Corporations whose Board of Directors members are not independent of the business are more likely to be involved in financial statement fraud than are corporations with a large percentage of outside board members (Beasley et al., 1996, 2000; Dechow, 2011; Skousen \& Wright, 2006). Additionally, corporations with ineffective audit committees are more likely to have financial statement fraud (Abbott et al., 2000, 2001; Beasley et al., 2000; Skousen \& Wright, 2006). In an article published in the Journal of Accountancy (2002, p. 42) about Enron, C. William Thomas states, "Secrecy became the order of the day for many of the company's trading contracts, as well as its disclosures."

When the corporate culture emphasizes financial performance and stock price, managers may be able to rationalize fraudulent and other unethical behavior by telling themselves that they are acting in the best interest of the company. They may also use the rationalization that "everyone here lies and cheats." In a 2009 economic crime survey conducted by Price Waterhouse Coopers (PWC, 2009), 33\% of U.S. executives who responded stated that the rationalization "Others do it and so it's okay" presents a risk of fraud. This rationalization behavior allows a manager to act upon the pressure and opportunity to commit fraud because he/she can make himself/herself believe that it is the right thing to do. Another common rationalization is the expectation that the company will make up for the fraud in future accounting cycles. In his article "Looking the Other Way: Managers' Rationalization of Possible Frauds," Alan Sandersen (2012) quotes Leon A. La Rosa, Jr., CFE, CPA, MST, chair of litigation support services, Gocial Gerstein, LLC as stating, "The issue always gets back to the integrity of the people. If senior managers tell middle managers that moving expenses forward one quarter is okay because they'll recover it the next, then the middle managers take on that attitude with simple things like travel expense reports."

\section{JAPANESE BUSINESS CULTURE}

Japanese cultures that contributed to the rise of Japan as an economic power also play a role in the business culture that can make fraud detection more difficult. Japanese and Western cultures differ in their attitudes toward right and wrong behavior. In his book, Japan: Understanding \& Dealing with the New Japanese Way of Doing

\footnotetext{
${ }^{1}$ Black, W.K. YouTube video titled William K. Black's Theory of Corporate Fraud provides some insight into corporate culture and fraud. Retrieved from https://www.youtube.com/watch?v=pOgYbvWQYfQ
} 
Business, Lafayett De Mente (2012, p. 460) states, “To the typical Japanese, right or wrong is not so much based on an unvarying, universal code of ethics or principles as it is upon time, place, the people involved, and other circumstances." While Westerners consider sincerity to be truthfulness and honesty, the Japanese makoto means "to properly discharge all of one's obligations so that everything will flow smoothly and harmony will be maintained. It also means being careful not to say or do anything that would cause loss of face" (p. 460).

The Japanese idea of $w a$, which is the ancient word for peace and harmony, creates a business culture in which employees and managers work together in circles instead of in hierarchical layers of bureaucracy (Lafayett De Mente, 2012). The Japanese word jicho means "to respect oneself" (p. 683). Respecting oneself means to avoid doing or saying anything that would make one become subject to criticism. Additionally, the concept of kata, which is the way of doing things, contributes to the Japanese culture of mutual cooperation, group effort, tendency to follow the masses, and reluctance to oppose anyone openly.

The Japanese have a strong tendency to become dependent on others and will feel like a victim when someone hinders their efforts (Lafayett De Mente, 2012). Japanese managers have been known to turn against foreign executives who they feel have wronged them or are incompetent.

Another component of Japanese culture that can hinder fraud detection is a type of group-think (called shudan ishiki) which emphasizes the goals of the group over individual goals and responsibilities (Lafayett De Mente, 2012). Additionally, adhering to the concept of on, Japanese employees may be reluctant to disclose improper behavior of others in positions of authority. According to Japanese culture, one should not do or say anything beyond what is prescribed by his position. This aspect of the culture prescribes when and how to bow when greeting each other, for example. Giri is a personal code to fulfill one's obligations. Under giri, Japanese employees extend service and loyalty to their superiors, and superiors shows a sense of responsibility and appreciation to the subordinates.

Japanese culture places emphasis on serenity and harmony. Lafayee De Mente (2012, p. 669) states, “A primary rule in traditional Japanese society was that nothing should be allowed to disrupt the surface serenity of existence." More emphasis is placed on serenity than on truthfulness; therefore, the Japanese do not consider it wrong to lie if being truthful will upset or cause harm to others.

\section{OLYMPUS CORPORATION}

\section{Corporate Culture}

An outside panel appointed by Olympus to investigate alleged financial statement fraud called the company's management "rotten to the core." (Asahi Shimbun, 2011) The report alleges that Tsuyoshi Kikukawa, former CEO and Chairman of the Board, along with a small group of other executives at Olympus, persuaded banks to help them to hide billions of dollars in losses. It is customary in Japan for boards to be comprised of individuals who have risen through the company ranks. The Board of Directors at Olympus Corporation was made up largely of insiders who were fearful of speaking up against top executives of the company. In the report, the board of directors is described as consisting of "yes-men" and that the board was "emasculated."

The culture at Olympus Corporation, like many Japanese corporations, values loyalty. A November 17, 2011 NPR story (Craft, 2011) stated,

The insider mentality at Olympus is reminiscent of Tokyo Electric Power, whose Fukushima Daichi nuclear plant became the worst nuclear disaster since Chernobyl... The overriding instinct at such firms is to hide mistakes at all costs. The sense that we have to be loyal to our predecessors, that we can't blow the whistle, we can't criticize, because of these bonds of loyalty.

Olympus Corporation obviously had a culture of keeping quiet and not rocking the boat. Michael Woodford commented one month after he was named president of the company, "Harmony and consensus have their place and time but scrutiny and challenging....leads to better decision-making. You have to be able to confront" (Gwyther, 2012). 


\section{Michael Woodford, Gaijin "Salary-Man" CEO}

Michael Woodford, a native of Liverpool, England, grew up in a working-class neighborhood in a family whose living circumstances were less than fair. His experience with Olympus Corporation began in 1980 when he joined KeyMed, a British maker of industrial and surgical equipment that was partially owned by Olympus. Woodford was an excellent salesman and was promoted from sales manager to managing director as a reward for increasing profits. In the early 1990's, KeyMed became the most profitable part of the Olympus realm and Woodford was deemed a rising star by management. When Kikukawa became CEO in 2001, he made Woodford the executive managing director and chairman of the board of Olympus Europe Holding, which generated more than 40 percent of Olympus's global revenue. Shortly before he was appointed president and COO of Olympus, Woodford said "He recognized me, and he promoted me. But he didn't understand the medical business. He had come up from the camera business. He knew that he needed free cash, and I was the one who could do that" (Greenfeld, 2012). In the early 2000's, the company was experiencing financial difficulties. While the camera division was faltering, the surgical equipment businesses that Woodford managed were performing very well. The company began purchasing other companies, a move that made Woodford uncomfortable. When he questioned Kikukawa about some of the acquisitions, he was assured that the acquisitions would not continue.

In April, 2011, Woodford was promoted to President and Chief Operating Officer of Olympus Corporation, making him the first non-Japanese person to ever rise through the ranks of a Japanese company to become its president. While there were other gaijin (outsider) corporate presidents at the time, Woodford states, "I was one of only four foreign company presidents in all Japan (Howard Stringer-Sony, Carlos Ghosn-Nissan, Craig NaylorNippon Sheet Glass), but the only gaijin 'salary-man' to have made it to the top." Woodford recalls that Kikukawa told him, "I haven't been able to change the company in the way it needs to be changed. I think you can" (Woodford, 2012).

In his book, Exposure: Inside the Olympus Scandal: How I Went from CEO to Whistleblower, Michael Woodford states (2012, p. 158),

In most companies the president has a principal influence over events, but at Olympus my authority as the new incumbent had already proved diluted, much to my frustration. Before my appointment Kikukawa had fulfilled the role of both president and chairman (not the ideal model for good corporate governance), but when I became president, he introduced for the first time in the company's history, the title of CEO, which is a Western concept.

He further states, "This gave Kikukawa ultimate power, at board level, to hire and fire, and also gave him control over the key issue of determining the remuneration of his fellow directors."

\section{Michael Woodford, Whistleblower}

Shortly after becoming president of the company, Woodford received an e-mail alerting him of an article in the Japanese magazine, Facta, alleging financial statement fraud at Olympus Corporation. The article alleged that Olympus Corporation had been overstating the value of the businesses acquired and had not properly recorded losses related to the acquisitions. When he began questioning his colleagues at the company about the allegations in the article, he was told that they had been instructed not to bring it to his attention. This is when his relationship with Kikukawa and board deteriorated. At a subsequent lunch meeting with Kikukawa and Group President Hisashi Mori, Woodford noticed that the two Japanese men had plates of sushi, while he was served a tuna sandwich. During the meeting, Woodford asked if the allegations of fraud were true, to which Kikukawa responded, "Some parts." When Woodford pressed Mori for more details, the answers he received were vague and incomplete. Frustrated, he asked Mori, "Who do you work for?" Expecting Mori to reply, "Olympus," Woodford was stunned when Mori answered, "I work for Mr. Kikukawa. I am loyal to Mr. Kikukawa." It was at this moment that Woodford realized that "something was terribly, terribly wrong here" (Greenfeld, 2012).

Woodford began pressing the board to come clean about the fraudulent transactions and asked that he be promoted to CEO. To his surprise, Kikukawa agreed that he would step down, make Woodford CEO, stop attending weekly management meetings, and allow Woodford to nominate his own board. When these changes were proposed 
to the board, however, they resisted. While Woodford was named CEO, this was announced only on the company's English language website, but not on the Japanese site. Woodford commissioned an independent auditor to review the transactions in question. On October 13, he shared their report with the board. Woodford recounts that the report, "...frightened the heck out of them. You had this big, prestigious firm saying these payments needed to be investigated." Along with the report, Woodford sent a letter to Kikukawa asking for his and Mori's resignations. The following day, the board met to discuss the situation; however, the agenda was really to take a vote to dismiss Woodford as CEO. It was a unanimous vote to dismiss Woodford from all offices in the corporation. Woodford was asked to turn over all company electronics and vacate the premises. Later, the company made the public statement, "We have said that the reason for the dismissal was because his management style caused a significant divergence between him and other executives" (Greenfeld, 2012). The afterword of Woodford's book (Woodford, 2012) contains the following quote from Jake Adelstein,

Michael Woodford is not just a whistleblower - he's a truth teller and a hero. These are rare things. As a society we may laud honesty and integrity, but when someone actually stands up for those principles, we think to ourselves, 'what a nutter.' In Japan, this is all the more noticeable thanks to a culture that emphasizes decorum and keeping the status quo. But there is no such thing as a society immune to corruption and hypocrisy. Loyalty triumphs over principles, lawsuits and money muzzle the naysayers, and intimidation keeps people quiet.

\section{WHISTLEBLOWER PROTECTION}

A whistleblower is one who reveals wrongdoing within an organization to the public or to the authorities. In its 2012 Report to the Nations, the Association of Certified Fraud Examiners (ACFE) stated, "Perhaps the most prevalent trend in the detection data is the ongoing importance of tips, which have been the most common method of initial detection since we first began tracking this data in 2002" (p. 14). The 2012 report analyzes 1,388 fraud cases across the globe. According to the ACFE's 2012 Report to the Nations (ACFE, 2012, p. 14), "Frauds are much more likely to be detected by tips than by any other method." Further, companies that provide anonymous tip hotlines have a higher likelihood of detecting fraud by a tip (51\%) than firms without a hotline (35\%). In the study conducted by the ACFE, fifty percent of all tips about wrongdoing came from employees.

Most countries provide some type of legal protection for whistleblowers. The United States passed the Whistleblower Protection Act in 1989. The UK's Public Interest Disclosure Act (PIDA) was enacted in 1998. New Zealand's Protected Disclosures Act was passed in 2000. Canada enacted the Public Servants Disclosure Protection Act in 2005. Lagging behind, Japan enacted a whistleblower protection act in 2006. Japan's Whistleblower Protection Act has been criticized because it applies only to employees; if the whistleblower leaves the company, he/she is no longer protected under the Act. Additionally, the Act does not penalize companies that punish whistleblowers. The first case of a whistleblower being protected was in 2012, eight years after the Act was enacted. In June 2012, Japan's Supreme Court ruled in favor of Masaharu Hamada, an Olympus Corporation employee who reported a supplier's complaint that the Olympus Corporation was luring away its employees. Hamada sued in 2008, stating that the Olympus Corporation treated him unfairly after he reported the supplier complaint. In 2011, the Tokyo High Court ordered Olympus to pay Hamada 2.2 million yen $(\$ 28,000)$. Olympus appealed this decision, which was sent to Japan's Supreme Court (Kageyama, 2012).

\section{DISCUSSION QUESTIONS}

1. How does a country's culture affect the business culture within it?

2. In what ways does the Japanese culture hinder fraud detection and deterrence?

3. In a statement made in Tokyo on January 6, 2012, Michael Woodford stated,

The cross-shareholding system in Japan, while clearly serving the country well in the years following the Second World War, is in today's world harmful due to the unwritten convention that one must never publicly criticize another. Such a compliant approach removes one of the essential safeguards in relation to governance and also allows the boards of companies which are underperforming to remain in office. I hope this reality will be seriously debated in relation to legislative changes which would strengthen the country's corporate governance and in turn the vibrancy of the Japanese economy. I believe this issue of 
the weaknesses created by the cross-shareholding system is the most important single factor Japan needs to address to be successful in confronting the obvious challenges it faces, in this ever more competitive world.

What is the cross-shareholding system in Japan? How does it hinder efforts to detect and deter fraud?

4. Compare the whistleblower protection acts of various countries to Japan's act. What differences do you see? How does culture affect these acts? How does the protection act affect whistleblower behavior?

5. If you were called in to investigate an alleged fraud in a Japanese company, how would your understanding of Japanese culture affect your investigative techniques?

6. Do an Internet search of Olympus Corporation accounting scandal. What has happened in regards to the case since this case study was written? Summarize your findings.

7. What can the current Board of Directors of the company do to deter this type of fraud?

\section{AUTHOR INFORMATION}

Dr. Anita Morgan has more than 15 years of experience teaching accounting, both in class and online. She holds a Bachelor's degree in Accounting from St. Mary of the Woods College, an MBA from Ball State University, and a Doctorate of Business Administration-Accounting from Nova Southeastern University. Anita is also a licensed CPA. Dr. Morgan became interested in forensic accounting a few years ago and has since developed and implemented programs of study in fraud examination for two colleges. She is the Director of the MPPA program at Ohio Northern University, which offers a Forensic Accounting and Auditing Track. E-mail: a-morgan.4@ onu.edu (Corresponding author)

Cori Burnside is an undergraduate student at Indiana University East, majoring in Business Administration with a concentration in Accounting. She is also completing the Financial Forensic Investigations minor. Miss Burnside will graduate in May 2015 and plans to then sit for the CPA exam and pursue a career as a forensic accountant.

\section{REFERENCES}

1. Abbott, L., Park, Y., \& Parker, S. (2000). The effects of audit committee activity and independence on corporate fraud. Managerial Finance, 26(11), 55-68.

2. Abbott, L., \& Parker, S. (2000). Audit committees and auditor selection. Auditing: A Journal of Theory and Practice, 19(2), 47-66.

3. Abbott, L., \& Parker, S. (2001). Audit committees and auditor selection: Evidence from auditor switches. Research in Accounting Regulation, 15, 151-166.

4. $\quad$ ACFE. (2012, November 28). 2012 Report to the Nations. Retrieved from http://www.acfe.com/uploadedFiles/ACFE_Website/Content/rttn/2012-report-to-nations.pdf

5. Banerjee, N. (2002, Feb 26). Enron's many strands: Corporate culture; At Enron, lavish excess often came before success. The New York Times. Retrieved July 19, 2013 from

http://www.nytimes.com/2002/02/26/business/enron-s-many-strands-corporate-culture-enron-lavishexcess-often-came-before.html?pagewanted=all\&src=pm

6. Beasley, M. (1996). An empirical analysis of the relation between the board of director composition and financial statement fraud. The Accounting Review, 71(October), 443-465.

7. Beasley, M. C. (1999, March). Fraudulent financial reporting: 1987-1997 -- An analysis of U.S. public companies. Retrieved March 3, 2013, from http://www.coso.org/publications/FFR_1987_1997.PDF

8. Beasley, M. C. (2000). Fraudulent financial reporting: Consideration of industry traits and corporate governance mechanisms. Accounting Horizons, 14(4), 441-454.

9. Chang, Y. (2009, Dec 7-14). Whistleblower Protection Act. Retrieved from http://whistleblowers.typepad.com/files/japan-whistleblower-protection-law-2004.pdf

10. Craft, L. (2011, Nov 16). Olympus scandal could hasten disclosure changes. NPR. Retrieved July 19, 2013 from http://www.npr.org/2011/11/16/142385395/olympus-scandal-could-hasten-corporate-disclosurechanges

11. Dechow, P. (2011). Predicting material accounting misstatements. Contemporary Accounting Research, 28(1), 17-82. 
12. Dunn, P. (2004). The impact of insider power on fraudulent financial reporting. Journal of Management, 30(3), 397-412.

13. Dye, D. (2013, July 19). Foreign policy blogs. Retrieved from http://foreignpolicyblogs.com/2011/10/18/what-does-the-firing-of-olympus-ceo-teach-us-about-japan/

14. Greenfeld, K. (2012, Feb 16). The story behind the Olympus scandal. Bloomberg Businessweek. Retrieved July 19, 2013 from http://www.businessweek.com/articles/2012-02-16/the-story-behind-the-olympusscandal

15. Gwyther, M. (2012, Nov 1). Japan: The descent of the rising sun. Management Today. Retrieved July 19, 2013 from http://www.managementtoday.co.uk/go/news/article/1155926/japanthe-descent-rising-sun/

16. Kageyama, Y. (2012, June 29). Whistleblower wins in Supreme Court in Japan first. Seattle Times. Retrieved August 1, 2013 from http://seattletimes.com/html/businesstechnology/2018564418_apasjapanwhistleblower.html

17. Lafayett De Mente, B. (2012). Japan: Understanding \& dealing with the new Japanese way of doing business! Essex, VT: Phoenix Books.

18. Loebbecke, J. (1989). Auditors' experience with material irregularities: Frequency, nature, and detestability. Auditing: A Journal of Practice and Theory, 9(Fall), 1-28.

19. McGuire, R. (2003, June 17). WorldCom's deadly culture. Biznetdaily. Retrieved July 19, 2013 from http://www.wnd.com/2003/06/19325/

20. PWC. (2009). 2009 global economic crime survey. Retrieved July 19, 2013 http://www.pwc.com/us/en/forensic-services/publications/2009-global-economic-crime-survey.jhtml

21. Sandersen, A. (2012, Aug 21). Looking the other way: Managers' rationalization of possible frauds. Retrieved July 19, 2013 from http://skcdocs.com/blogsktx/2012/08/looking-the-other-way-managersrationalization-of-possible-frauds/\#sthash.F2Lme8e7.dpbs

22. Shimbun, A. (2011, Dec 7). Olympus board signals it may quit by late-Feb. The Asahi Shimbun. Retrieved July 19, 2013 from http://ajw.asahi.com/article/behind_news/social_affairs/AJ201112070058

23. Skousen, C. J., \& Wright, C. J. (2006, Aug 24). Contemporaneous risk factors and the prediction of financial statement fraud. Available at SSRN: http://ssrn.com/abstract=938736 or http://dx.doi.org/10.2139/ssrn.938736

24. Summers, S., \& Sweeney, J. (1998). Fraudulent misstated financial statements and insider trading: An empirical analysis. The Accounting Review, 73(January), 131-146.

25. Thomas, C. (2002). The rise and fall of Enron. Journal of Accountancy, 194(4), 41-48.

26. Woodford, M. (2012). Exposure: Inside the Olympus scandal: How I went from CEO to whistleblower. New York, NY: Penguin Group. 


\section{TEACHING NOTE}

\section{Case Overview}

The Olympus Corporation accounting scandal is an interesting case, not only from the accounting fraud standpoint, but also from the corporate culture viewpoint. Because the appointment of an outsider (non-Japanese) to a position of power in a Japanese company is so rare, it is especially interesting to examine the case of an outsider CEO blowing the whistle on accounting fraud within the company. Japanese culture, which values harmony and loyalty, played a role in this case of financial statement fraud and its cover-up. Although several executives of the company were aware of the fraud, they did not report it. This case discusses some elements of Japanese culture that may have influenced the decision of Olympus Corporation's management to perpetrate and cover up financial statement fraud and introduces the question of how much national culture influences management behavior, especially related to fraud.

Excited about his new appointment to CEO of Olympus Corporation, Michael Woodford was shocked to learn through a magazine article that the company may be "cooking the books." He was even more shocked by the reaction to his questions by the Board of Directors and other corporate executives. Instead of receiving answers, he was treated with hostility. When his questions went unanswered, Woodford blew the whistle on the fraud. This case provides the opportunity to teach students about the impact of a nation's culture on corporate culture, and subsequently on fraud.

\section{Teaching Objectives}

Because of its discussion of the impact of national and corporate culture on financial statement fraud detection and deterrence, this case study may be used in Accounting, International Business, Business Ethics, Fraud Examination, and Organizational Behavior courses. Upon successful completion of the case study, students should be able to:

- $\quad$ Discuss the role national culture plays on corporate culture

- Identify components of Japanese culture that may hinder fraud deterrence and detection

- $\quad$ Discuss the role a nation's legal system plays in fraud detection and deterrence

- $\quad$ Examine the impact of national and corporate culture on ethical behavior

\section{Pedagogy}

The case provides some insights into the relationships between national and corporate culture and their impact on management behavior, especially as it relates to fraud. The case works best when students have a basic understanding of corporate culture and financial statement fraud. Assignment of the following reading prior to introducing the case study will provide a starting point for discussion regarding the impact of national culture on corporate culture for students:

- Kelm, O. (2012, Sept 18). National culture vs. corporate culture. Texas Enterprise. Retrieved from http://www.texasenterprise.utexas.edu/article/national-culture-vs-corporate-culture

Additionally, the following readings will help students to understand what financial statement fraud is and how corporate culture contributes to it:

- $\quad$ Center for Audit Quality. (October 2010). Deterring and detecting financial reporting fraud: A platform for action. Retrieved from http://www.thecaq.org/publications/

- $\quad$ Beasley, M. S., Carcello, J. V., Hermanson, D. R., \& Neal, T. L. (May 2010). Fraudulent financial reporting 1998-2007: An analysis of U.S. public companies. COSO. Retrieved from http://www.coso.org/guidance.htm 
Questions that might be addressed either in class or assigned to students include:

- What is financial statement fraud and what is its impact on corporations, employees, stockholders, and the economy?

- Describe a scenario in which corporate culture may create an environment conducive to financial statement fraud.

- What is the impact of national culture on corporate culture? How might national culture contribute to a corporation culture conducive to financial statement fraud?

A good way to introduce the case study is by showing a YouTube ${ }^{2}$ video about the Olympus Corporation accounting scandal. It may be helpful if the instructor provides a brief explanation of what happened at Olympus Corporation. While students do not need to understand the accounting complexities of the case in order to complete this case study, they might find it helpful to have some knowledge of what happened. The instructor should explain that the company failed to accurately report some investment losses, which made the company appear to be in a better financial position than it actually was.

The instructor should show the YouTube video (or provide the link) of the Capital Account interview of Michael Woodford ${ }^{3}$ during which he discusses the impact of Japanese culture on corporate culture. Ask students to identify the cultural concepts discussed in the case study during the video. Discuss the impact of national culture on corporate culture. Pose the question, "How might this culture impact fraud detection and deterrence?"

After students have read the case study, it may be helpful to provide whistleblower acts from different countries and help students to compare and contrast them. The instructor may provide the following links to students:

- Japan's Whistleblower Protection Act http://www.drasuszodis.lt/userfiles/Japan\%20Whistleblower\%20Protection\%20Act.pdf

- $\quad$ Derbyshire, H. (2013, June 25). Whistleblower protection in the UK. http://www.skadden.com/insights/whistleblower-protection-uk

- $\quad$ US National Whistleblowers Center http://www.whistleblowers.org/

- $\quad$ SEC Office of the Whistleblower http://www.sec.gov/whistleblower

- $\quad$ Sankowicz, D., \& Henry, S. (March 2012). Update on whistleblowing in France. International Bar Association on Legal Practice Division. http://www.paulhastings.com/assets/pdfs/whistleblowing_article.pdf

- Wysong, W., Bing, Y., \& Boeringer, C. (2011, September 29). Blowing the whistle on corruption in the U.S. and China. Corporate Compliance Insights.

http://www.corporatecomplianceinsights.com/blowing-the-whistle-on-corruption-in-the-u-s-and-china/

Instructors might ask:

- What elements of the Acts would you expect to motivate someone to come forward and blow the whistle?

- How confident do you think employees are that they will be protected under these Acts?

The instructor might assign students to make short class presentations on different aspects of Japanese and British culture. This could lead to a discussion comparing and contrasting Japanese and British culture. The following questions can be used to generate discussion regarding why Woodford was willing to come forward and why his questions were met with hostility:

\footnotetext{
2 Michael Woodford keynote speech at the Association of Certified Fraud Examiners Annual Conference. Retrieved from http://youtu.be/Nci3bM0s-xk

${ }^{3}$ Capital Account news segment Ex-CEO of Olympus blows the Whistle on Fraud and a Culture of Dysfunction in Japan. Retrieved from http://youtu.be/AwDgIS4orZg
} 
- How do Japanese and British cultures differ?

- $\quad$ Are there differences that might explain Woodford's willingness to come forward and the reaction of his Japanese colleagues?

\section{Assignment Questions}

1. How does a country's culture affect the business culture within it?

2. In what ways does the Japanese culture hinder fraud detection and deterrence?

3. In a statement made in Tokyo on January 6, 2012, Michael Woodford stated,

The cross-shareholding system in Japan, while clearly serving the country well in the years following the Second World War, is in today's world harmful due to the unwritten convention that one must never publicly criticize another. Such a compliant approach removes one of the essential safeguards in relation to governance and also allows the boards of companies which are underperforming to remain in office. I hope this reality will be seriously debated in relation to legislative changes which would strengthen the country's corporate governance and in turn the vibrancy of the Japanese economy. I believe this issue of the weaknesses created by the cross-shareholding system is the most important single factor Japan needs to address to be successful in confronting the obvious challenges it faces, in this ever more competitive world.

What is the cross-shareholding system in Japan? How does it hinder efforts to detect and deter fraud?

4. If you were called in to investigate an alleged fraud in a Japanese company, how would your understanding of Japanese culture affect your investigative techniques?

5. Do an Internet search of Olympus Corporation accounting scandal. What has happened in regards to the case since this case study was written? Summarize your findings.

6. What can the current Board of Directors of the company do to deter this type of fraud? 